\title{
Exploring Distinguish Approach to Opinions of Indian Educators and Students towards ICT
}

\author{
Chaman Verma \\ Research Scholar, Dept. of CSE, JJT University, Rajasthan, (India) \\ lchaman.verma@gmail.com
}

\begin{abstract}
In today's arena Information and communication technology (ICT) is the prime pillar of academic and economic growth. Indian technological growth has been reached up to peak, due to higher involvement of ICT in research and education. The author sensed that there is necessity to evaluate the opinions of educators and students regarding ICT. This paper focuses on exploring meaningful difference between students and educators towards ICT awareness in respect to their occupation. This study has been carried out on students and faculty of six Indian Universities. The nine hundred four samples have been collected from two states. To find significant difference between student and faculty popular statistical techniques such as F-test and one way ANOVA test has been applied. The outcomes this paper reveal that there is meaningiful differnece between opinion of students and educators for their occupation. More than nine hundred educators and students from Haryana and Punjab have participated in this research.
\end{abstract}

Index Terms- Degree of Freedom, F-Test, Scatteredness, Discriminating Power.

\section{INTRODUCTION}

Information and Communication Technology can be considering as combination of two sectors, Information Technology and Communication. In past two decade, India has achieved remarkable development in both sectors. Information technology industry in India consists of information technology enabled services (ITES), hardware production and software development. India is using rapidly ICT resources in research, projects and higher education. Evaluating impact of ICT is crucial understanding the role of ICT for Indian educational development. India government has taken ICT initiatives in a big way and has laid down a National ICT policy, which is reflected and implemented through various Government Departments and Ministries. It is being implemented through energetic activities of National Informatics Center and encouragements form University grant commission, All India council of technical education and Department of science \& technology throughout the country [1]. In India, a lot of work on investigating the ICT awareness in Institutions has been carried out. The Government of India has been taking persistent steps to advancement of ICT awareness in Universities. Kozma (2003) stated that ICT allows teaching and learning activities by educational innovations and by connecting students and teachers to each other and to a vast array of human and informational resources around the world [2]. Ulka Toro, Milind Joshi (2012) stated that use of ICT for education is a horizontal activity that requires elements from different verticals to come together to enable meaningful learning experiences for the students [3]. Sucheeta Kak, Sunita Gond (2015) 
concluded that digital India Programme anticipated that with dedicated leadership, willpower and control and an integrated framework comprising of the government, ICT interventions in the rural areas will undoubtedly pave way towards sustainable growth [4]. M.J. Philomina and S. Amutha (2016) found significant difference between male and female teacher educators towards. They have also found subject wise opinion difference among them. It is also proved that Ph.D. scholars won from M.Ed. and M.Phil. Scholars towards ICT awareness in relation to various aspects [5]. Md. Abul Kalam Siddekike, M. Nasiruddin Munshi, M. Abu Sayeed, (2011) concluded that in this age of ICT the university library services should be redesigned to meet the users' needs and to provide modern information services facilitated by ICT. It has been also recommended that for the developing countries' libraries to follow the developed countries and adopt new technological facilities [6]. Beena Mathur (2012) described that girl students have lower ICT awareness as compare to boy students regarding ICT usage in education [7]. Nabin Thakur (2014) has not found any meaningful difference among teachers towards ICT in relation to their gender [8]. U. Pratik (2013) found no significant difference between male and female B.Ed. student's attitude towards computer. He found identical opinions towards ICT in students [9]. Dubey. R. (2010) found meaningful gender wise difference among teacher educators. In his paper, female faculty won from male faculty for their positive opinions towards computer [10].

\section{RESEARCH OBJECTIVES AND HYPOTHESIS}

The present study is conducted with the prime aim of study the occupation wise difference among educators and students regarding ICT awareness. The following are the objectives and concerned hypotheses:

1. To study the scatteredness difference between opinion of student and Faculty towards ICT awareness.

H01: There is no significant difference between scatteredness in the opinion of student and faculty towards ICT awareness.

2. To study the scatteredness difference between scatteredness in the opinion of boy and male towards ICT awareness.

H02: There is no significant difference between scatteredness in the opinion of boy and male towards ICT awareness.

3. To study the scatteredness difference between opinion of girl and female towards ICT awareness.

H03: There is no significant difference between scatteredness in the opinion of girl and female towards ICT awareness.

4. To study equality of mean of opinion in between student and faculty towards ICT awareness in relation to occupation. 
H04: There is no significant mean difference of opinion in between student and faculty towards ICT awareness in relation to occupation.

\section{RESEARCH DESIGN \& METHODOLOGY}

A quantitative research method has been used in present study. For collection the primary samples, a survey technique have been conducted in universities of Haryana and Punjab states of India. The samples are collected using structured questionnaire in five point Likert scale. Total 70 independent variables were assumed. After applying Discriminating power test (DP), only 35 independent variables found to be considerable.

Table 1: Discriminating power of variables

\begin{tabular}{|c|c|c|c|c|}
\hline S.No. & $\overline{\mathrm{DP}}$ & Frequency & Variable No's. & Remarks \\
\hline 1 & $0.40-0.9$ & 26 & $\begin{array}{c}9,12,14,16,18,19,23,25,31,32,33,36,37,41,43,46,47,48,49, \\
50,51,52,54,55,56,61,\end{array}$ & $\begin{array}{l}\text { Very } \\
\text { Good }\end{array}$ \\
\hline 2 & $\begin{array}{c}0.30- \\
0.39\end{array}$ & 09 & $7,8,24,28,30,44,59,62,66$ & Good \\
\hline 3 & $<0.19$ & 35 & $\begin{array}{c}1,2,3,4,5,6,10,11,13,15,17,20,21,22,26,27,29,30,34,35,38, \\
39,40,42,53,57,60,63,6567,68,69,70\end{array}$ & Poor \\
\hline
\end{tabular}

(Source: Authors)

The data from Table 1 reflects that only twenty six variables are found very good and there is no further requirement for updating as the DP is in range of 0.40-0.9. There are nine variables are found good as the DP is in range of 0.30-0.39. There is fifty percent variables are rejected accept due to poor status as the DP is greater than 0.19. This paper divides the participant's occupation into the six groups, which are shown above in Table 1.

Table 2: Occupation Distributions

\begin{tabular}{|c|c|c|c|c|c|}
\hline Student & Faculty & $\begin{array}{c}\text { Boy } \\
\text { Student }\end{array}$ & $\begin{array}{c}\text { Male } \\
\text { Faculty }\end{array}$ & $\begin{array}{c}\text { Girl } \\
\text { Student }\end{array}$ & $\begin{array}{c}\text { Female } \\
\text { Faculty }\end{array}$ \\
\hline $560(\mathrm{~N})$ & $344(\mathrm{~N})$ & $274(\mathrm{~N})$ & $175(\mathrm{~N})$ & $286(\mathrm{~N})$ & $169(\mathrm{~N})$ \\
\hline $62(\mathrm{P})$ & $38(\mathrm{P})$ & $61(\mathrm{P})$ & $39(\mathrm{P})$ & $62.9(\mathrm{P})$ & $37.1(\mathrm{P})$ \\
\hline \multicolumn{2}{|c|}{904} & \multicolumn{2}{|c|}{449} & \multicolumn{2}{c|}{455} \\
\hline
\end{tabular}

$\mathrm{N}=$ Count, $\mathrm{P}=$ Percentage, (Source: Authors) 
Above Table 2 shows the distributions of occupation into three groups. The first group is consisted of 560 students and 344 faculties, the second group is made up of two hundred seventy four (274) boy student and one hundred seventy five (175) male faculty and third group is comprise of two hundred eighty six (286) girls student and one hundred sixty nine (169) female faculty. The total nine hundred four participants are participated in this study. Out of total participants 904, study includes $62 \%$ students and $38 \%$ faculty members. There is $39 \%$ male faculty and $61 \%$ boy student is involved. There are $37.1 \%$ female faculty and $62 \%$ girl student are included. The total count for participants is 904.

The assumed hypotheses are tested using F-Test and one way ANONA test available in Microsoft Excel with extra Add-ins named Analysis Toolpack and Analysis Toolpack-VBA.

\section{DATA COLLECTION AND SAMPLING}

In order to gather primary data or samples from various Universities, a stratified random sampling technique is used to collect nine hundred four samples from higher educational institutions of Punjab and Haryana states. The following Table 2 displays the demography of participated Universities.

Table 3: Demography of Universities

\begin{tabular}{|c|c|c|c|c|c|}
\hline S.No. & University & State & Status & $\begin{array}{c}\text { Student } \\
\mathrm{N}=560 \\
\% \text { age }=62\end{array}$ & $\begin{array}{c}\text { Faculty } \\
\mathrm{N}=344 \\
\% \text { age }=38\end{array}$ \\
\hline 1 & CDLU & \multirow{3}{*}{ Haryana } & Government & $88(16)$ & $56(16)$ \\
\hline 2 & GJUST & & Government & $86(15)$ & $52(15)$ \\
\hline 3 & SGT & & Private & $96(18)$ & $52(15)$ \\
\hline 4 & $\mathrm{PU}$ & \multirow{3}{*}{ Punjab } & Government & $95(17)$ & 48 (14) \\
\hline 5 & $\mathrm{CU}$ & & Private & $112(20)$ & $86(25)$ \\
\hline 6 & GKU & & Private & 83 (14) & $50(15)$ \\
\hline
\end{tabular}

(Source: Authors)

Table 3 shows the participation of two state's faculty and students from 6 higher educational Universities. There are 3 Universities are considered from each state. The total 344 faculty and 560 students have participated. The total 269 students were from government and 190 students were from private Universities. Similarly the total count for government faculty is 156 and private faculty is 188 . The total 1000 survey forms were distributed to students and faculty and received back 904 only. 
Therefore, $90.4 \%$ response rate was calculated as given below:

$\begin{array}{lll}\text { \#Received } & \times 100 \quad \leftrightarrow \quad \frac{904}{1000} & \end{array}$

\section{RESULTS AND DISCUSSIONS}

This section explores the findings of results after testing of null hypotheses and analysis of students and educators' opinions regarding ICT awareness for their occupation.

\subsection{Testing of Scatteredness Difference using F- Test}

The scatteredness shows, how much response of participants are scattered while they have answered. In another words we can say that scatteredness is way to show significant difference between variances. Therefore, F-test which is called frequency test is appropriate to find out difference in scatteredness of student's and faculty's opinion towards ICT awareness in relation to occupation. We have applied F-test at 5\% significant level on 35 independent variable. The following Table 4 has been framed to show results of applied F-Test.

Table 4: Scatteredness using F-Test

\begin{tabular}{|c|c|c|c|c|c|c|}
\hline $\begin{array}{c}\text { Independent } \\
\text { Variables }\end{array}$ & Student & Faculty & Boy & Male & Girl & Female \\
\hline Mean & 3.61 & 3.99 & 3.58 & 3.83 & 3.64 & 4.01 \\
\hline Variance & 0.14 & 0.27 & 0.15 & 0.06 & 0.15 & 0.10 \\
\hline Observation & 35 & 35 & 35 & 35 & 35 & 35 \\
\hline Degree of Freedom & 34 & 34 & 34 & 34 & 34 & 34 \\
\hline F-value & \multicolumn{3}{|c|}{0.04} & \multicolumn{2}{|c|}{2.48} & \multicolumn{2}{|c|}{1.47} \\
\hline F-Critical value & \multicolumn{3}{|c|}{0.56} & \multicolumn{2}{c|}{1.77} & \multicolumn{2}{c|}{} \\
\hline
\end{tabular}

(Source: Author)

The data from Table 4 represents scatteredness evaluation of participants in relation to their occupation. There are six groups under occupation variable are shown such as student, faculty, boy, male, girl and female. This table also shows mean, variance, observation and degree of freedom. The after F-Test applied, calculated F-value and F-Critical value has been calculated and shown in last row of above table.

\subsubsection{Evaluation of Hypothesis H01:}

It is evident from Table 4 that calculated F-value is 0.04 , is smaller than observed F-Critical value which is $0.56(0.04<0.56)$ at $5 \%$ significant level with 35 degree of freedom. Hence, it is not 
significant up to $5 \%$ level. Therefore, no statistically significant difference is found in scatteredness of student and faculty opinions towards ICT. Hence, first null hypothesis H01 "There is no significant difference between scatteredness in the opinion of student and faculty towards ICT awareness" is failed to reject. Thus, it reveals that there is no significant difference between scatteredness in participant's opinions in relation to occupation.

\subsubsection{Evaluation of Hypothesis H02:}

The data from Table 4 proves that calculated F-value is 2.48 , is greater than observed F-Critical value which is $1.77(2.48>1.77)$ at $5 \%$ significant level with 35 degree of freedom. Hence, it is found significant up to $5 \%$ level. Therefore, a statistically significant difference is found in scatteredness of boy and male variable. Thus second null hypothesis H02" There is no significant difference between scatteredness in the opinion of boy and male towards ICT awareness" is failed to accept here. Hence, it reveals that there is significant difference between scatteredness in boy's and male's opinion towards ICT awareness. It means their responses are found to be scattered but meaningful difference has been found in their scatteredness.

\subsubsection{Evaluation of Hypothesis H03:}

Data from Table 4 is concluded the calculated F-value is 1.47, is smaller than the observed F-Critical value which is $1.77(1.47<1.77)$ at $5 \%$ significant level with 35 degree of freedom, which is found no significant at 5\% level. Hence, third null hypothesis H03 "There is no significant difference between scatteredness in the opinion of girl and female towards ICT awareness" is failed to reject here. Therefore, no statistically significant difference is found in scatteredness in opinion of girl and female. It infers that there is no significant difference between scatteredness in girl's and female's opinions towards ICT awareness. It means their responses are found to be scattered but no meaningful difference has been found in their scatteredness.

\subsection{Testing of Mean Difference using One-Way ANOVA Test}

This section shows that implement of single factor ANOVA (analysis of variance) on students and faculty related to their occupation. It is also called one-way ANOVA is used to find out that the means of several populations are all equal or not. Whenever we need to compare the mean of three or more than three groups, the ANOVA test is appropriate. Here we have used single factor ANOVA to analyze the differences between occupation groups and their ICT awareness. There scores were categorized into six groups: Group 1: student; Group 2: faculty; Group 3: boy; Group 4: male; Group 5: girl; Group 6: female. 
Table 5: One-Way ANOVA Test Group Summary

\begin{tabular}{|c|c|c|c|c|}
\hline Groups & Count & Sum & Average & Variance \\
\hline Student & 35 & 43.21 & 1.23 & 0.35 \\
\hline Faculty & 35 & 32.53 & 0.93 & 0.20 \\
\hline Boy & 35 & 42.83 & 1.22 & 0.08 \\
\hline Male & 35 & 31.75 & 0.91 & 0.05 \\
\hline Girl & 35 & 43.29 & 1.24 & 1.05 \\
\hline Female & 35 & 28.89 & 0.83 & 0.06 \\
\hline
\end{tabular}

(Source: Author)

The data from Table 5 explores the summary of occupation groups. It also shows total count of 35 variables, sum of variances, average, calculated mean scores for groups and variances. .Means and variances are comparing groups' ICT awareness of student's and faculty's opinions in relation to occupation. It is transparent from the above data that mean values are not equal for each group. Hence, summary table states that significant mean difference among groups.

Table 6 Single Factor ANOVA on Occupation and ICT Awareness

\begin{tabular}{|c|r|r|r|r|r|r|}
\hline \multicolumn{7}{|c|}{ ANOVA-Single Factor } \\
\hline Source of Variation & \multicolumn{1}{|c|}{ SS } & \multicolumn{1}{c|}{ df } & MS & F & P-value & F crit \\
\hline Between Groups & 6.44 & 5 & 1.29 & 4.29 & 0.00 & 2.26 \\
\hline Within Groups & 61.23 & 204 & 0.30 & & & \\
\hline Total & 67.67 & 209 & & & & \\
\hline
\end{tabular}

(Source: Author)

\subsubsection{Evaluation of Hypothesis H04}

The data from Table 6 evident that calculated $\mathrm{F}$ value is 4.29 , is greater than Critical $\mathrm{F}$ value which is 2.26 (4.29>2.26). Hence mean values of students and faculty in relation to their occupation have been found not identical. Therefore, significant difference has been found between group's means. The Pvalue is equal to 0 , which lie in between the range of 0 to 1 , infers that mean values are not identical for all groups. Every group have not identical mean as shown in Table 5. Therefore, according to one way ANOVA analysis null hypothesis H04 "There is no significant mean difference of opinion in between student and faculty towards ICT awareness in relation to occupation" is failed to accept here. It has been concluded that student's mean scores are differ from faculty's mean scores $(1.23>0.93)$. There is a significant difference between mean scores of student and faculty towards ICT awareness. It is also found that there is significant difference between opinion of boy students \& male faculty and girls students \& female faculty towards ICT awareness. Therefore, no identical means has been found between boy and male group (1.22>0.91) as well as in girl and female group (1.24>0.83).Hence, somewhere significant difference exist between opinion of boy students \& male faculty and girl students \& female faculty opinions towards information and communication technology awareness. 


\section{CONCLUSIONS}

This research has been carried out to investigate the opinions of faculty and students towards ICT awareness in relation to their occupation. It has been concluded that occupation variable affected students and faculty opinions towards ICT awareness. It has concluded that there is meaningful difference exist between opinion of boy students and \& male faculty towards ICT awareness. The girl students and female faculty has been also affected from occupation variable here. The mean difference has been found between them towards ICT awareness. One side, it has been revealed that there is no significant difference between scatteredness in student and faculty opinions but another side, a significant difference between scatteredness in boy's and male's opinion towards ICT awareness. It has also evident that there is no significant difference between scatteredness in girl's and female's opinions towards ICT awareness. This paper helps to reflects mirror of real picture of ICT awareness. This study provides support to ICT policy makers, ICT vendors, University's authorities and state administration to understand the trend of ICT used in research and education.

\section{Acknowledgment}

This study is a part of doctorate of philosophy thesis of the author. The author gives his thanks to all participants for such an amazing participation. In last, the author would like to thank his wife to give her precious and priceless support in writing of this article.

\section{REFERENCES}

[1] Sharma D, Singh V, "ICT infrastructure and human resource performance- A study of university in the western Himalayas of India", International Journal of advanced engineering application, 7(1), 86-109.2010.

[2] Kozma R (ed), R.Kozma, "Technology, Innovation, and education change: A Global Perspective .2003 pp 1-19. ISBN-13: 978-1564842305.

[3] Toro U, Joshi M, "ICT in Higher Education: Review of literature from the Period 2004-2011", International Journal of Innovation, Management and Technology, 3(1), 20-23.2012.

[4] Kak S, Gond S, "ICT for service delivery in Rural India -scope, challenges and present scenario", IOSR Journal of Computer Engineering, 17(6), Ver.1, 12-15.2015.

[5] Philomina M.J, S. Amutha,"Information and communication technology awareness among teacher educators", International Journal of Information and Education Technology, 6(8), 603-606.2016.

[6] Kalam A, Siddekike M. Munshi N, Sayeed M, "The Adoption of Information and Communication Technology (ICT) in the University Libraries of Bangladesh: An Exploratory Study", International Seminar on Vision 2021: the role of libraries for building digital Bangladesh, 153-164.2011.

[7] Mathur M, "A Study on the ICT Awareness of M.Ed. Trainees", International Journal of Business Management and Economic Research, 3(4): 573-578.2012.

[8] Thakur N, "A Study on Awareness of Trained Teachers in relation to Information and Communication Technology", International Journal of Research and Method in Education, 4(1), 611.2014.

[9] Pratik U, "Students attitude towards computer -A study", International Journal of Creative Research Thoughts, 1 (5), 1-4. 2013.

[10] Dubey. R., "A study of teacher's attitude towards computer", Journal of Teacher Education in Developing Nations, 1(1), 47-50. 2010. 